Environment, Biodiversity \& Soil Security
(EBSS)
http://jenvbs.journals.ekb.eg//

\title{
Cellulolytic Activity of Trichoderma reesei and Bacillus subtilis Against the Plant Pathogen Pythiumdebaryanum
}

\author{
A.A. Salem and H.M. Abdel-Rahman* \\ Agricultural Microbiology Dept., Faculty Agriculture, Moshtohor, Benha Univ., \\ Egypt.
}

\begin{abstract}
$\mathbf{T}$ HIS work focused on the degradability of Pythium debaryanum cell wall by cellulase enzymes produced by Bacillus subtilis MK537378 and Trichoderma reesei MK934489.B. subtilis showed higher Exo-1,4- $\beta$-D glucanase and Endo-1,4- $\beta$ D-glucanase activities than T. reesei while the highest $\beta$-glucosidase activities were recorded for $T$. reesei. Antagonistic activities against $P$. debaryanum were investigated by the tested $B$. subtilis and T. reesei. Moreover, the cellulolytic activity of both $B$. subtilis and $T$. reesei against $P$. debaryanum was confirmed by using Congo red staining technique. Microscopic observations showed clear hyphal lysis and degradation of the fungal cell wall in a dual plate assay. Results of the greenhouse experiment emphasized that the inoculated tomato seeds with $B$. subtilis or $T$. reese $i$ in the presence of $P$. debaryanum showed $73.5 \%$ and $76 \%$ reduction in disease incidence, respectively as compared to the seed treated with pathogen alone $(85 \%)$. Dehydrogenase activity (DHA) of soil rhizosphere was significantly increased in all inoculated soil with $B$. subtilis and/or T. reesei compared with uninoculated ones. The inoculation of tomato with $B$. subtilis and $T$. reesei in presence of $P$. debaryanum induced high activities of peroxidase, polyphenoloxidase, and chitinase by increasing 49.3, 55.2, and 56.9\%, respectively, over the control. The grow thparameter sand yield of thetoma to plants significantly increased in response to the inoculation of B. subtilis MK537378 and T. reesei MK934489 compared to individual inoculation.
\end{abstract}

Keywords: Cellulase-producing bacteria, Biocontrol, Pythiumdebaryanum, Defense enzymes, and Tomato yield .

\section{Introduction}

Tomato (Lycopersicon esculentum L.) is considered to be a major vegetable crop grown worldwide. In Egypt, tomato cultivation covers about $32 \%$ of the total vegetable-growing area; with total production being approximately $16 \%$ of total vegetable production (Elshahawy et al., 2018; Abd-Elgawad 2020). There is little information available about the possibility of Pythium spp. inciting damping-off and root rot diseases on tomato in Egypt (Elshahawy et al. 2018). A major threat to agriculture is soil-borne diseases which extensively decline the crop yield. The genus Pythium contains many species that are important because of the economic losses that result from a reduction in yield associated with their diseases. Pythium spp. usually cause preand post-emergence damping-off, a disturbing agricultural disease. Pythiumis a soil-borne pathogen that produces sporangiospores and the life cycle occurs within the soil. The pathogen infects plants primarily through the root system. (Zitnick-Anderson et al. 2017). Synthetic pesticidesaremainly a method for controlling damping-off (Muriungi et al. 2014). Concerns about environmental pollution associated with the use of synthetic pesticides in crop productionhave increased the need for alternative control methods (Rosenzweig et al. 2001).

${ }^{*}$ Corresponding author: E-mail: hany.abdelrahman@fagr.bu.edu.eg

Received: 5/4/2021; Accepted: 9/5/2021

DOI: $10.21608 /$ jenvbs.2021.71242.1132

C2021 National Information and Documentation Center (NIDOC) 
Biological control agents have been effectively used in controlling various diseases caused by Pythium spp. (Kipngeno et al. 2015 and El-Feky et al. 2019). Accordingly, Trichoderma is known to produce secondary metabolites and enzymes that attack or restrict the growth of other phytopathogenic fungi. Due to these properties, researchers agricultural field focused their attention on it to use in the biological control field (Taha et al. 2020). Moreover, rhizosphere bacteria are wonderful agents to control soilborne plant pathogens. Many species of bacteria such as Bacillus, Pseudomonas, Serratia and Arthrobacter have been used in controlling fungal diseases (Joseph et al., 2007; Ashwini and Srividya 2014; Ghazi et al. 2018). Nonpathogenic soil Bacillus species offer several advantages over other organisms as they form endospores and hence can tolerate extreme $\mathrm{pH}$, temperature and osmotic conditions. Bacillus species can colonize the root surface, increase plant growth and cause the lysis of fungal mycelia (Turner and Backman 1991 and Podile and Prakash, 1996).

Cellulases and related enzymes from certain bacteria and fungi are capable of degrading the cell wall of plant pathogens and controlling the plant disease (Saadia et al. 2008 andVinale et al. 2008). It has been reported that the $\beta-1,3-$ and $\beta$-1,6-glucanases from $T$. harzianum hydrolyzed filamentous fungal cell walls, inhibited the growth of fungi tested, and reduced the disease incidence by Pythium. (Bruce et al. 1995 and Kumar et al. 2014). Thus, a combination of microbial strains and their enzymes could be useful as biocontrol agents to protect the seeds and plants from plant pathogens. Many cellulolytic fungi including Trichoderma sp, Chaetomium sp, and cellulolytic bcateria such as Bacillus sp play vital role in agriculture by facilitating enhanced seed germination, rapid plant growth and flowering, improved root system as well as increased crop yields (Harman and Bjorkman, 1998 and Bae et al, 2009; Ashwini and Srividya, 2014).

The objectives of this current study were to investigate and confirm the role of cellulases enzymes produced by Trichoderma reesei MK934489 and Bacillus subtilis MK537378 for degrading the cell wall of P.debaryanum. Accordingly, using them for controlling Pythium disease in tomato.

\section{Materials and Methods}

\section{Microorganisms}

Bacillus subtilis MK537378 and Trichoderma reesei MK934489 strains were obtained from Agric. Microbiology Dept., Fac. of Agric., BenhaUniv., Egypt. The fungus P.debaryanum was obtained from Plant Pathology Dept., Fac. of Agric., BenhaUniv., Egypt. The originalbacterial and fungal cultures were maintained onnutrient agar and potato dextrose agar (PDA) slants, respectively. Maintenance media in the case of B.subtilis MK537378 and T.reesei MK934489 were supplied with $0.5 \%$ cellulose and stock cultures were keptat $5 \mathrm{C}$.

Fermentation and cellulase enzymes production

Modified Reese and Mandel's basal medium, (Salem and Abdel-Rahman, 2015) was used for cellulase enzyme production (Rice straw, 10; Proteose peptone, 0.25; $\left(\mathrm{NH}_{4}\right)_{2} \mathrm{SO}_{4}, 1.4$; Urea, 0.3; $\mathrm{KH}_{2} \mathrm{PO}_{4}, 2.0 ; \mathrm{CaCl}_{2} .2 \mathrm{H}_{2} \mathrm{O}, 0.3 ; \mathrm{MgSO}_{4} .7 \mathrm{H}_{2} \mathrm{O}$, $0.3 ;\left(\mathrm{g} \mathrm{L}^{-1}\right)$ Tween $80,1 \mathrm{ml}$ and $1 \mathrm{ml} . \mathrm{L}^{-1}$ of trace metal solution $\left(\mathrm{FeSO}_{4} .7 \mathrm{H}_{2} \mathrm{O}, 5.0 ; \mathrm{MnSO}_{4} .7 \mathrm{H}_{2} \mathrm{O}\right.$, 5.6; $\mathrm{ZnSO}_{4} .7 \mathrm{H}_{2} \mathrm{O}, 3.3$ and $\mathrm{CoCl}_{2} .2 \mathrm{H}_{2} \mathrm{O}, 2.0(\mathrm{mg}$ $\left.\mathrm{L}^{-1}\right)$. About $95 \mathrm{~mL}$ of the production medium were dispended into 250 mLErlenmeyerflasks, sterilized and inoculated with $5 \mathrm{ml}$ of a 2-days-old and 5-days-old inoculum of B.subtilis MK537378 and T.reesei MK934489, respectively. The inoculated flasks were incubated with shaking at $150 \mathrm{rpm}$ and $30^{\circ} \mathrm{C}$ for 3 days. The cultureswere centrifuged at $4000 \mathrm{rpm}$ for $30 \mathrm{~min}$ at $4^{\circ} \mathrm{C}$. Thesupernatant was used forthe measurement of cellulase activity.

\section{Cellulase enzymes determination}

Endo-1,4- $\beta$-D-glucanase (CMCase) and Exo$1,4-\beta-D$-glucanase activity were assayed using a modified method described by Wood and Bhat (1998). Cellobiase activity was determined by a modification of the method described by Berghem and Petterson (1974). The released glucose was determined using dinitrosalicylic acid method.

\section{Antagonistic activity}

B.subtilis MK537378 and T.reesei MK934489 were screened on PDA medium (containing $1 \% \mathrm{CMC}$ ) for their ability to inhibit the growth of $P$. debaryanum in dual Petri dishes culture test as described by Hariprasad and Niranjana (2009). The previous bio-agents were tested against the pathogenic fungi using dual culture technique. Briefly, the bacterialand fungal strains were seeded at the edges of $90 \mathrm{~mm}$ Petri plates containing PDA and incubated for $36 \mathrm{hr}$ at $28 \pm 2{ }^{\circ} \mathrm{C}$. Then, afive-mm diameter disk of pathogenic fungus was placed on the sub-terminal of the another plate edge. Plates were incubated at $28 \pm 2{ }^{\circ} \mathrm{C}$ for $4-7$ days. After incubation, the plates were examined for clear zone using congo red staining technique (Hendricks et al., 1995)

Biocontrol agents of pathogen and the germination of tomato seeds

For determining the effect of B. subtilis MK537378 or T. reesei MK934489 in dividually 
or in presence of $P$. debaryanum on tomato seeds germination, the method of Bákonyi et al., (2013) was used. The spore's suspension $\left(10^{4} / \mathrm{ml}\right)$ of $T$. reesei MK934489 and $P$. debaryanum and cell suspension $\left(10^{8} / \mathrm{ml}\right)$ of $B$. subtilis MK537378 were used by rate $35 \mu$ per seed.

Biocontrol agent and pathogen inoculum preparation

The inocula of $T$. reesei MK934489 and $P$. debaryanum were prepared by standard procedures according to Rini and Sulochana, (2007) using a one-liter jar containing sorghum seeds, sand and water medium. After sterilization, the medium was inoculated with the mycelial disc of $T$. reesei MK934489 or P. debaryanum and was incubated for two weeks at $25^{\circ} \mathrm{C}$. However, the inoculum of $B$. subtilis MK537378 was prepared by growing the bacterial strain in the nutrient broth medium at $30{ }^{\circ} \mathrm{C}$ with continuous shaking $(140 \mathrm{rpm})$ up to optimum growth. The cells were harvested by centrifugation (4000 rpm) at 4 for $10 \mathrm{~min}$. The cells were suspended using a physiological salt solution.

\section{Seed coating}

Before seeding, tomato seeds (approximately $6 \mathrm{~g})$ were surface sterilized with $1 \% \mathrm{Ca}(\mathrm{OCl})_{2}$ for $3 \mathrm{~min}$, washed thoroughly in sterilized water. Three grams of the wet seeds were mixed by stirring with $5 \mathrm{ml}$ of either B. subtilis MK537378 cell suspension and /or $T$. reesei MK934489 sporessuspension. Then, the coated seeds were spread on plastic trays and stored at $25^{\circ} \mathrm{C}$ away from direct sunlight to dry for $2 \mathrm{hr}$.

Efficacy of B. subtilis MK537378 and T. reesei MK934489against P. debaryanum

In 2020, a greenhouse experiment was conducted at the Faculty of Agriculture Experiment Station, Fac. of Agric., Benha Univ., Egypt to study the efficacy of biocontrol agents, i.e., B. subtilis MK537378 and T. reesei MK934489 individually or in their combined mixture, against damping-off disease of tomato caused by $P$. debaryanum were evaluated under greenhouse conditions. Sterilized plastic pots (30 $\mathrm{cm}$ diameter) were filled with $10 \mathrm{~kg}$ sterilized soil (Table 1) that was mixed with $P$. debaryanum inoculum at a rate of $3 \%$. Potsand soil were sterilized by using $5 \%$ formaldehyde solution then left to dry to remove formaldehyde two weeks before use. Infested pots were irrigated for seven days before sowing. Ten tomato seeds (cv. 'strain B') were sown in each pot and five replicate pots were itemized for each treatment in a completely randomized experimental design. Befor esowing, Three-quarters of tomato seeds were coated with either B. subtilis MK537378 and/or T. reesei MK934489 suspensions.
Subsequently, each pot was drenched with $5 \mathrm{ml}$ of B. subtilis MK537378 inoculum $\left(10^{8} \mathrm{CFU} \cdot \mathrm{ml}^{-1}\right)$ or $5 \mathrm{~g}$ of $T$. reesei MK934489 inoculum ( $10^{5}$ spores. $\mathrm{g}^{-1}$ ) individually or in their combined mixture. the boost additions of bio-agent strains were added, 30 and 50 days after sowing (DAS). The experiment included the following treatments: non-infested soil (control), soil infested with $P$. debaryanum only, $P$. debaryanum + T. reesei, $P$. debaryanum + B. subtilis, and P. debaryanum $+T$. reese $i+B$. subtilis. In two equal doses, nitrogen, phosphorus, and potassium were added at a rate of 3, 4, and 3 gpot $^{-1}$ as ammonium sulphate $(20.5 \%$ $\mathrm{N})$, calcium superphosphate $\left(15.5 \% \mathrm{P}_{2} \mathrm{O}_{5}\right)$, and potassium sulphate $\left(48 \% \mathrm{~K}_{2} \mathrm{O}\right)$, respectively. Pots were kept under greenhouse conditions until the end of the experiment.

\section{Disease assessment}

The percentage of pre- and post-emergence damping-off and the percentage of survival plants were recorded at 30DAS asdescribed by (Elshahawy and El-Mohamedy, 2019).

\section{Determination of dehydrogenase activity}

Dehydrogenase activity was determined periodically at initial, 30, 60 and 90 DAS in soil samples from the tomato rhizosphere using methods described by Schinner et al. (1996).

\section{Determination of the chlorophyll content}

The effect of the treatments on the chlorophyll contents in the tomato leaves was determined at75 DAS. Five leaf disks were collected from tomato leaves (five leaves from every plant and five plants per replicate of every treatment). Chlorophyll was extracted from tomato leaf disks according to the method described by (Fadeel 1962) and was determined spectro-photometrically (SCO-Tech, SPUV-19, Germany) using the wavelength 662, and 644 $\mathrm{nm}$ for chlorophyll $\mathrm{a}$, and $\mathrm{b}$, respectively. The pigments (as $\mathrm{mg} / \mathrm{g}$ fresh weight) were calculated using the formula adapted by Wettestein (1957).

\section{Determination of the defense enzymes}

Peroxidase, polyphenoloxidase, and chitinase in tomato were estimated at 75 DAS according to the method described by Lee (1973), Bashan et al. (1985), and Monreal and Reese (1969), respectively. Peroxidase activity was expressed as the increase in absorbance at $470 \mathrm{~nm} / \mathrm{g}$ fresh weight/ min. Polyphenoloxidase activity was expressed as the increase in absorbance at 475 $\mathrm{nm} / \mathrm{g}$ fresh weight/minute. Chitinase activity was expressed as $\mathrm{mM} \mathrm{N}$-acetyl glucose amine equivalent released / gram fresh weight /60 min at $540 \mathrm{~nm}$.

\section{Plant growth and yield assessment}

At the end of the growing season (110 DAS), 
average of plant height, number of branches, plant dry weight, plant yield and estimated yield per feddan were calculated.

\section{Statistical analysis}

Analysis of variance (ANOVA) was performed using CoStat version 6.400 (CoHort software, Monterey, CA, 93940, USA). Mean values among treatments were compared by the Duncan test at $5 \%$ level $(\mathrm{p}=0.05)$ of significance and presented as the mean values \pm standard deviation (SD).

\section{Results and Discussion}

Cellulase enzymes activity

Regrading cellulase three components i.e., Endo-1,4- $\beta$ D-glucanase [EC.3.2.1.4], Exo-1,4$\beta$-Dglucanase [EC.3.2.1.91] and $\beta$-glucosidase [EC. 3.2.1.21], their activities were detected (Table 2) for both B. subtilis MK537378 and $T$. reesei MK934489. B. subtilis MK537378 showed higher Exo-1,4- $\beta$-D glucanase and Endo-1,4- $\beta$ D-glucanase activity than T. reesei MK934489. However, the highest $\beta$-glucosidase activities were recorded for $T$. reesei MK934489. Many reports confirmed the ability of Trichoderma spices and Bacillus subtilis to produce large amount of cellulases for examples (Montero et al. 2007 and Ihrmark et al., 2010) on Trichoderma sp. and Ashwini \& Srividya, (2014) on Bacillus subtilis.

Inhibitory effect of P. debaryanum by B. subtilis MK537378 and T. reesei MK934489

Since B. subtilis MK537378 and T. reesei MK934489 showed high potent to produce cellulase enzymes, it was of interest to investigate (in vitro) their antagonistic activity against $P$. debaryanum. Data illustrated in (Fig. 1) showed antagonistic activity of B. subtilis MK537378 and $T$. reesei MK934489 against $P$. debaryanum.
Confirming of cellulolytic activity by B.subtilis MK537378 and T.reesei MK934489 against P.debaryanum

Cellulolytic activity of both $B$. subtilis MK537378 and T.reesei MK934489 against P. debaryanum was confirmed by using Congo red staining technique. Plates that showed antagonistic activity were stained with Congo red dye for thirty minutes and then carefully washed by using sodium chloride solution several times. Data illustrated in Fig. 2 are showing zones of clearance in where B. subtilis MK537378 and T. reesei MK934489 were grown indicating cellulolytic activity.

On the other hand, places, where $P$. debaryanum grew, maintained the red color of Congo red stain that could be good evidence that antagonistic effect could be due to the cellulolytic activities of B. subtilis MK537378 and T. reesei MK934489. In this respect, many studies have been conducted confirming the role of cellulase in phytopathogen controlling. Saadia et al. (2008) reported that cellulase and xylanase are the major type of enzymes that contributed to the degradation of the cell wall of the phytopathogens. Woo \& Lorito (2007) and Vinale et al. (2008) confirmed that in the interactions of Trichoderma with plants, different kinds of metabolites may act as inducers of resistance. These metabolites are usually proteins including enzymes viz., cellulases, xylanases, chitinases, and glucanases. So, Trichoderma spp. was able to lyse and destroy conidiophores and spores of pathogen. These effects may be related to enzymes secreted such as cellulase, a-glucanase, and others (Harman 2006). Similar processes were reported against Pythium oligandrum, Phytophthora megasperma, and Pythium ultimum (Benhamou et al., 1999).

TABLE 1. Particle size distribution and chemical analyses of soil

\begin{tabular}{cccccccc}
\hline $\begin{array}{c}\text { Sand } \\
(\%)\end{array}$ & $\begin{array}{c}\text { Silt } \\
(\%)\end{array}$ & $\begin{array}{c}\text { Clay } \\
\mathbf{( \% )}\end{array}$ & $\begin{array}{c}\text { Texture } \\
\text { class }\end{array}$ & $\begin{array}{c}\text { Organic matter } \\
\left(\mathbf{g K g ~ g}^{-1}\right)\end{array}$ & $\begin{array}{c}\text { Bulk density } \\
\left(\mathbf{g c m}^{-3}\right)\end{array}$ & $\mathbf{p H}$ & $\mathbf{E C}\left(\mathbf{d S m}^{-1}\right)$ \\
\hline 22.5 & 31 & 46.5 & clay & 30.1 & 1.36 & 8.22 & 1.92 \\
\hline $\mathrm{Ca}^{++}$ & $\mathrm{Mg}^{++}$ & $\mathrm{Na}^{+}$ & $\mathrm{K}^{+}$ & $\mathrm{Cl}^{-}$ & $\mathrm{HCO}_{3}^{-}$ & $\mathrm{CO}_{3}^{--}$ & $\mathrm{SO}_{4}^{--}$ \\
3.43 & 1.73 & 3.95 & 0.98 & 3.93 & 4.14 & - & 1.93 \\
\hline
\end{tabular}


TABLE 2. Cellulase enzymes activity of B. subtilis MK537378 and T. reesei MK934489

\begin{tabular}{|c|c|c|c|}
\hline \multirow{2}{*}{ Microorganisms } & \multirow[b]{2}{*}{ Endo-1,4- $\beta$ D-glucanase } & Cellulases activity (U/mL) & \multirow[b]{2}{*}{$\beta$-glucosidase } \\
\hline & & Exo-1,4- $\beta$-D-glucanase & \\
\hline Bacillus subtilis & $2.9 \pm 0.020$ & $1.8 \pm 0.010$ & $0.7 \pm 0.002$ \\
\hline Trichoderma reesei & $2.8 \pm 0.030$ & $1.5 \pm 0.040$ & $1.1 \pm 0.005$ \\
\hline
\end{tabular}

Microscopical investigation on mycelial lysis of P.debaryanum

Since there was an antagonistic effect for B. subtilis MK537378 and T. reesei MK934489 against P.debaryanum and this antagonism could be due to the cellulolytic effect so it was of interest to investigate the lytic effect on mycelial growth of P.debaryanum-stained slides were microscopically investigated and theobtained results were illustrated in Fig. 3. As shown, it's clear that the mycelia of $P$. debaryanum were completely lysed at a lot of regions even the cytoplasm went out through the lysed regions.

The obtained results can be good and real evidence to say that the cellulolytic effect of $B$. subtilis MK537378 and T. reesei MK934489 is the most important reason for inhibition of $P$. debaryanum growth and development.

Similar results were obtained by Ashwini and Srividya (2014) who found that the fungal mycelium of Colletotrichum gloeosporioides OGC1 that grown with B. subtilis culture showed damage, swelling and distortions compared to the control that wasn't grown with any bacterial culture and did not appear these abnormal features. This indicates the mycolytic activity of the Bacillus culture against fungal pathogen. Similarly, Podile and Prakash (1996) reported that the lysis and dissolution of fungal mycelium of Aspergillus niger by B. subtilis AF1 strain were recorded.

\section{Effects on seeds germination}

Data of Table 3 showed the treatments of the tomato seeds (Strain B) with B.subtilis MK537378 or T. reesei. the culture showed $5 \%$ and $1.5 \%$ increase in seeds germination respectively compared to the untreatedone (control). Moreover, the inoculation of the seed with B. subtilis MK537378 or T. reesei MK934489 with the pathogen showed $73.5 \%$ and
$76 \%$ reduction in disease incidence, respectively as compared to the seed treated with pathogen alone $(85 \%)$. This trend of results is in agreement with Ashwini and Srividya (2014) who reported that the chili seeds that treated with Bacillus sp. culture showed $100 \%$ germination index like to the untreated seeds and $65 \%$ reduction in disease incidence by this treatment as compared to the seed treated with pathogen alone (77.5\%). Moreover, Kamil et al., (2007) reported that the sunflower seeds that were coated with $B$. licheniformis recordeda high reduction in infection percentage of $R$. solani damping-off (from 25 to $60 \%$ ) as compared with the pathogen alone.

Effects on $P$. debaryanum infection under greenhouse conditions

Datain Table 4 show that soil infested with P.debaryanum significantly increased the incidence of damping-of foftomato seedlings and severely reduced the survival plant rate $(11.7 \%)$ compared with thenon-infested control (93.3\%). Potting soil that was treated with $B$. subtilis MK537378 or T. reesei significantly increased the survival rate compared with that infested with P. debaryanum solely, ranging between 72.1 $79.2 \%$ (Table 4). However, higher survival rates of tomato seedlings were obtained inresponse to the combined inoculation of B. subtilis MK537378 and T. reesei MK934489 (83.0\%). The previous results indicate that the treatment with $B$. subtilis MK537378 and T. reesei, individually or in combination, resulted inbestdiseaseman agement than the control. These results are in agreement with those obtained by Khare \& Upadhyay (2009) and Kipngeno et al. (2015) who reported that The significantly lower percentage of pre-emergence damping-off of the seeds coated with either $B$. subtilis or $T$. spp under high disease pressure suggests that coating of seeds with $B$. subtilis or $T$. spp is effective against $P$. aphanidermatum damping-off.

Env. Biodiv. Soil Security Vol. 5 (2021) 


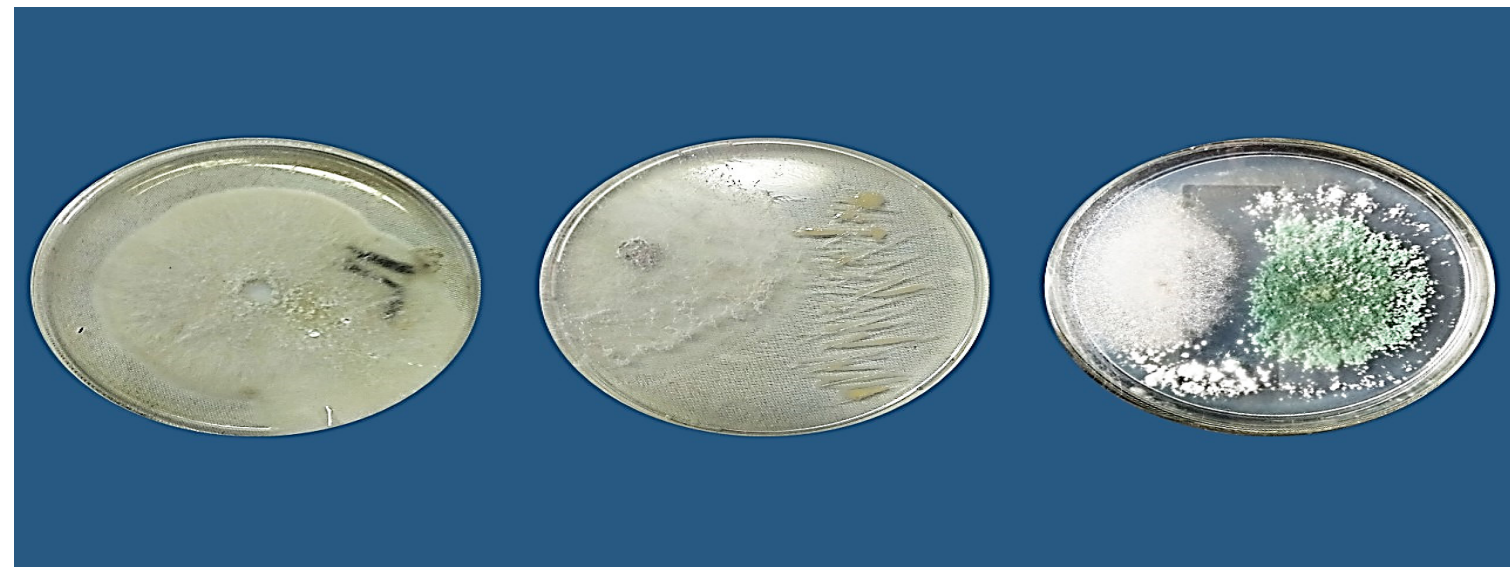

P.debaryanum. (control)

B. subtilis MK537378 against P.debaryanum.
T. reesei MK934489 against P.debaryanum.

Fig. 1. Antagonistic activity of $B$. subtilis MK537378 and T. reesei MK934489 against $P$. debaryanum

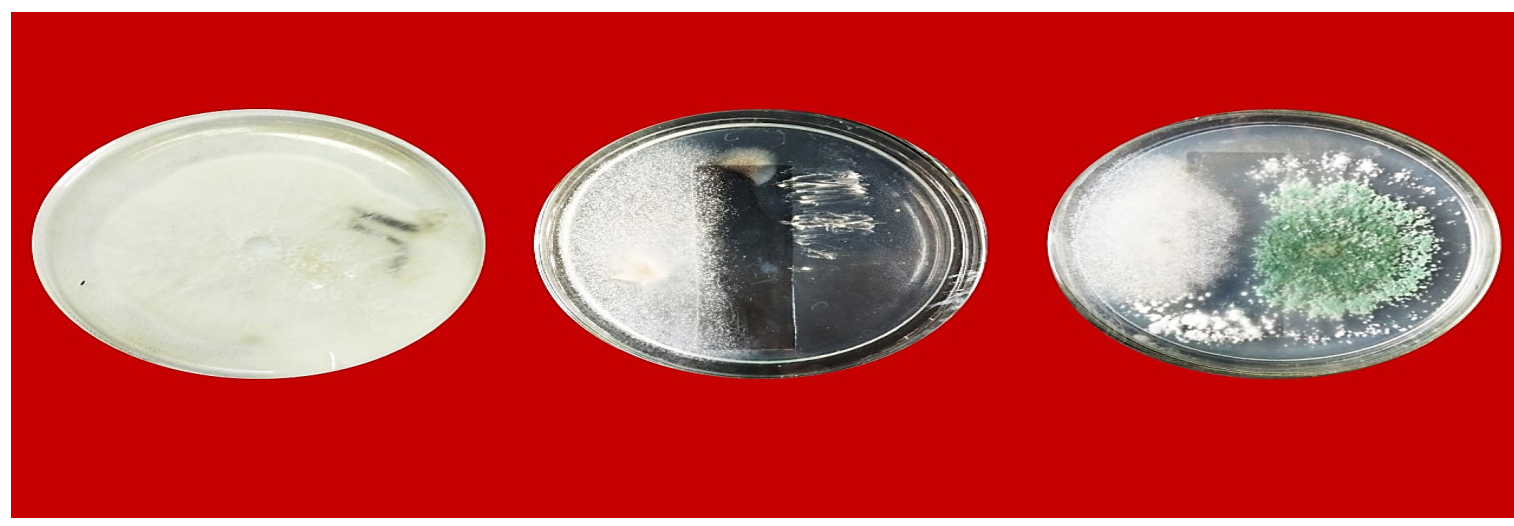

P.debaryanum. (control)

B.subtilis MK537378 against P.debaryanum.
T.reesei MK934489 against P.debaryanum.

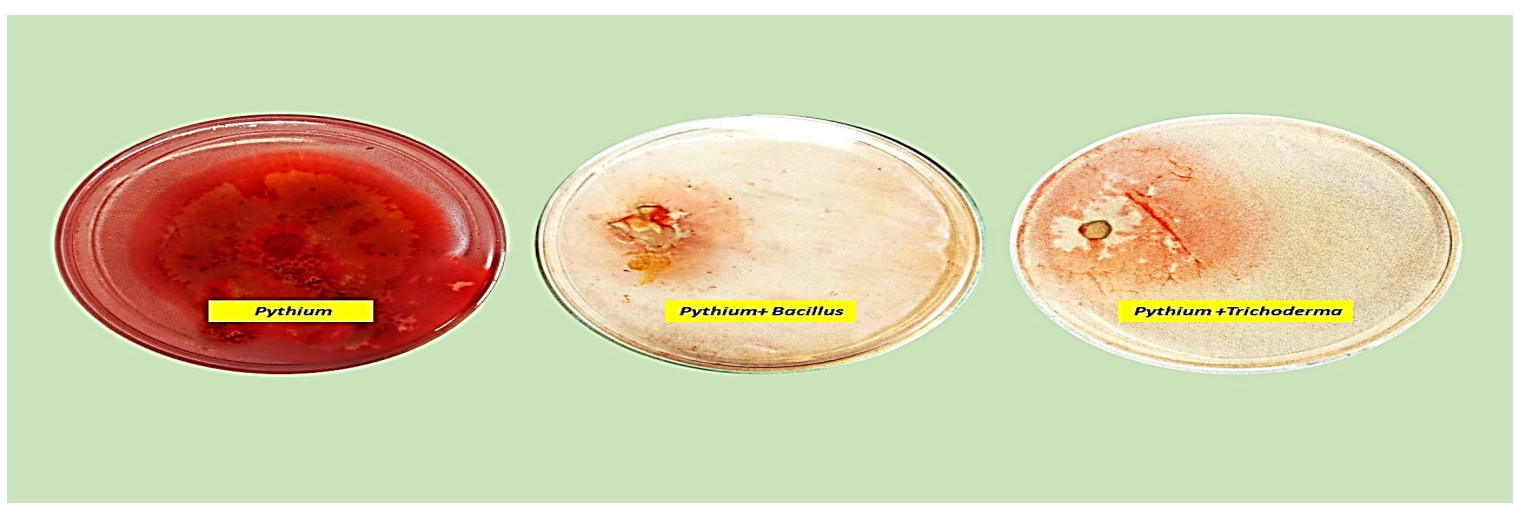

Fig. 2. Confirming of cellulolytic activities of B. subtilis MK537378 and T. reesei MK934489 against P.debaryanum using Congo red staining technique

Env. Biodiv. Soil Security Vol. 5 (2021) 

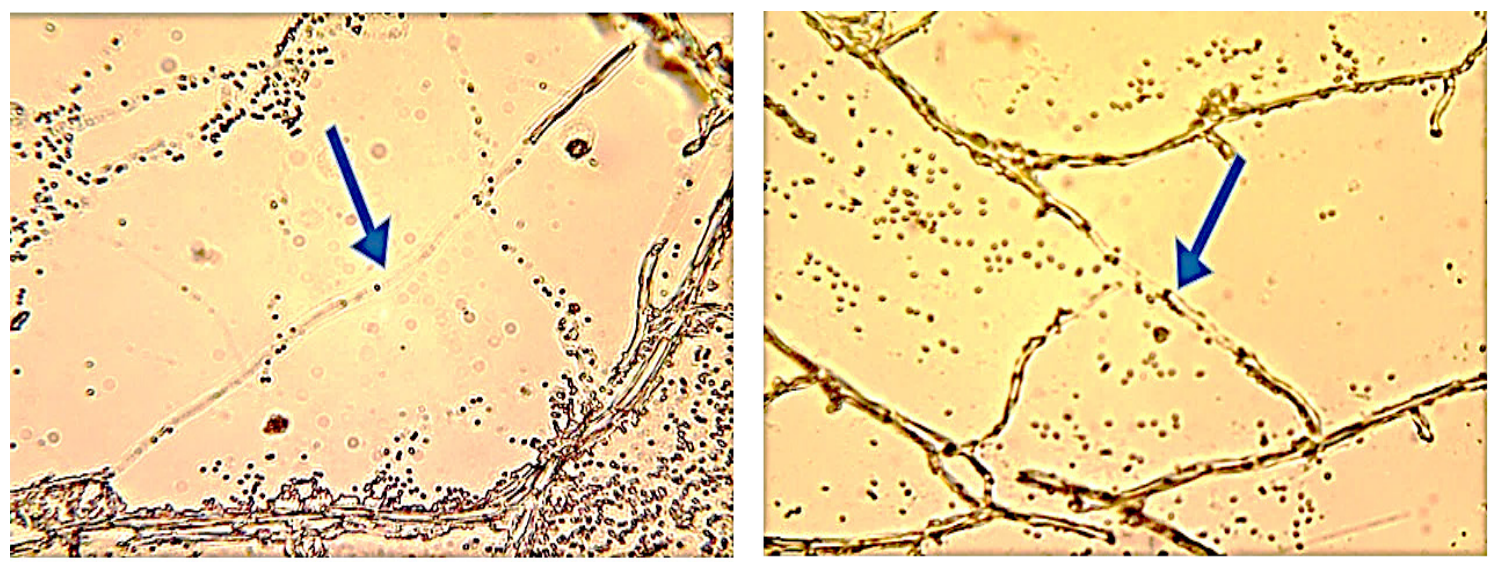

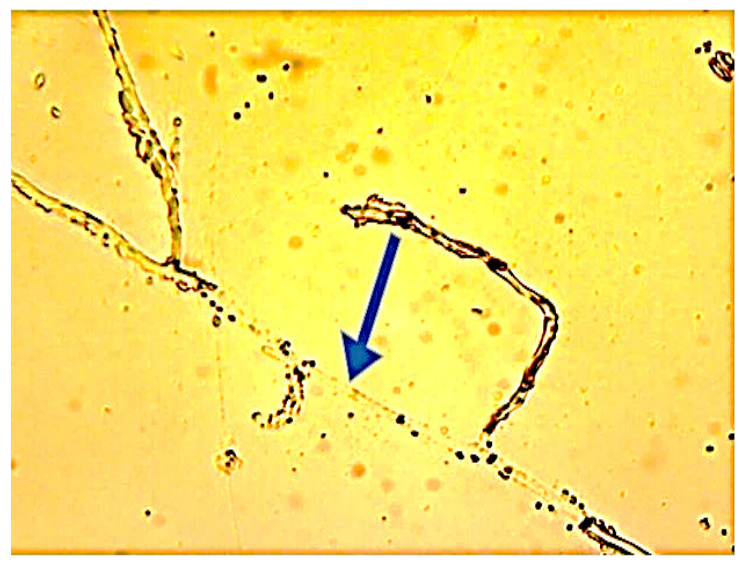

Dual growth of B.subtilis MK537378 and P. debaryanum

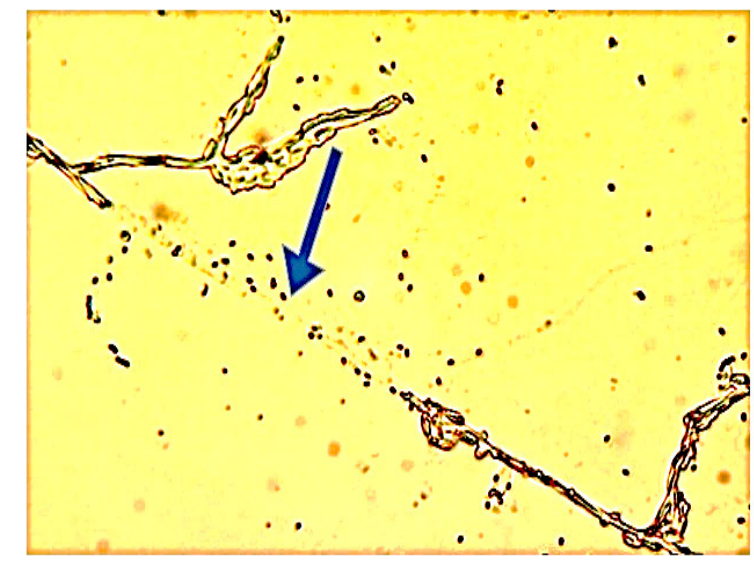

Dual growth of T.reesei MK934489 and P. debaryanum

Fig. 3. Microscopically investigation on mycelial lysis of $P$. debaryanum

The observations from this study indicate that seeds coated with B. subtilis MK537378 have cases of post-emergence damping-off less than those coated with $T$. reesei. This reveals a possibly higher efficacy of B. subtilis MK537378 in controlling $P$. debaryanum on tomato when compared to $T$. reesei. The variation could be due to the mechanism through which $B$. subtilis MK537378 or T. reesei MK934489 antagonize the pathogen as well as the ability of B. subtilis MK537378 to produce Endo-1,4-0 D-glucanase and Exo-1,4- $\beta$-D-glucanase by a higher amount than T. reesei MK934489 (Table $2)$. On the contrary, the treatment with the $B$. subtilis MK537378 was less effective in reducing the incidence of pre-emergence damping-off compared with individual treatment with $T$. reesei. The highest result was obtained by treating the soil with acombination of B. subtilis MK537378 and $T$. reesei, which reduced the incidence of preand post-emergence damping-off by $73.3 \%$ and $90.3 \%$, respectively.

The inoculation of B. subtilis MK537378 and T. reesei MK934489 significantly decreased the percentage of infection and increased the percentage of survival plant scompared with the individual in oculations. The decreases in the infection percentage in case of inoculation with B. subtilis MK537378 and T. reesei MK934489 maybe due to the synergistic effect between two microorganisms. They can produce enzymes that attack the cell components of pathogens (Sivan et al., 1984 and Elad, 2000). In this study, microscopic observations showed clear hyphal lysis and degradation of the fungal cell wall in a dual plate assay. So, the suppressive effect expressed by the B. subtilis MK537378 and T. reesei MK934489 strains might be due to that mechanism. Previous reports showed that 
microorganisms competent to degradecellulose, which is a major constituent of the fungal cell wall of oomycetes, play an important role in the biological control of fungal pathogens (Abdullah et al., 2008, Sharma, 2021 and Singh et al., 2021). However, a new mechanism has been added, namely, Trichoderma-induced resistance (Małolepsza et al., 2017) or Bacillus-induced resistance within the plant against fungal attack (Kloepper et al., 2004)

\section{Effects on dehydrogenase activity}

Dehydrogenase activity (DHA) was determined in the soil as a criterion for respiration rate and total microbial activity. Data in Table 5 show the values of dehydrogenase activity in the soil rhizosphere of tomato under-investigated treatments. Obtained data reveals significant increases in DHA values in all inoculated soil with B. subtilis MK537378 and/or T. reesei MK934489 compared with uninoculated ones. The highest values of DHA were revealed in tomato rhizosphere that treated with dual inoculated with B. subtilis MK537378 and T. reesei MK934489 in all determination periods. Higher values of DHA in dual application interpret the beneficial effect of inoculation with B. subtilis MK537378 and $T$. reesei MK934489 in proliferation and enhancement of microbial biomass in the rhizosphere (Abdel-Rahman, 2009).

By comparing the results of the dehydrogenase enzyme in the rhizosphere of the inoculated plants with B. subtilis MK537378 or T. reesei MK934489, it is found that DHA significantly increased in the case of B. subtilis MK53737 inoculation compared to inoculation with $T$. reesei MK934489. Higher records of DHA with B. subtilis MK537378 inoculation are likely to be due to the effective role of inoculation with previous strainfor enhancing colonization of introduced biocontrol strains for plant roots beside its role in enhancing the microbial community in the rhizosphere zone. Moreover, the inoculation might lead to the accumulation of available nutrients and thus stimulating the microorganisms in the rhizosphere. This was true in all experimental periods.

From the obtained data, it's noticed that the DHA in inoculated treatments with B. subtilis MK537378 and/or T. reesei MK934489 increased gradually from the first of the growing season up to $60 \mathrm{DAS}$ and decreased again until 90 DAS. The periodic increase of DHA may be due to the boost addition of biocontrol agent strains. The highest value of DHA in this period was observed with dual inoculation of two biocontrol agents' strains followed by individual inoculation with $B$. subtilis MK537378 and T. reesei MK934489. It worth to stated that the increment of DHA records at 60 DAS may be due to the plants in this period enter the flowering stage where root exudates increase and enhance the number and activity of microorganisms in the rhizosphere (shams et al, 2013 and Abdel-Rahman et al, 2017).

\section{Effects on chlorophyll contents in tomato}

Leafchlorophyll content oftomato significantly increased in the treatments that inoculated with $T$. reesei MK934489 and/or B. subtilis MK537378 compared with uninoculated ones. Inoculation of $T$. reesei MK934489 markedly increased the chlorophylla and chlorophyllb compared with the infested one. Data in the Table 7 showed that the treatment oftomato with B. subtilis MK537378 gave significant increases in the chlorophyll content intomato leaves by 3.49 and $4.07 \%$ respectively, compared to that inoculated with $T$. reesei. The present data are in accordance with those obtained by Gajera et al. (2013).

TABLE 3. Effect of seed treatment with B. subtilis MK537378 and T. reesei MK934489 on seed germination under lab. condition

\begin{tabular}{lcc}
\hline Treatments & Germination \% & Infection \% \\
\hline Uninoculated seeds & $95 \pm 1.3 \mathrm{~b}$ & $0 \pm 0.0 \mathrm{~d}$ \\
Seed with pathogen & $7.5 \pm 1.1 \mathrm{~d}$ & $85 \pm 1.08 \mathrm{a}$ \\
Seed inoculated with B. subtilis & $100 \pm 2.6 \mathrm{a}$ & $0 \pm 0.0 \mathrm{~d}$ \\
Seed inoculated with T. reesei & $98.5 \pm 1.8 \mathrm{a}$ & $0 \pm 0.0 \mathrm{~d}$ \\
Seed inoculated with $B$. subtilis + Pathogen & $88 \pm 1.4 \mathrm{c}$ & $11.5 \pm 1.04 \mathrm{~b}$ \\
Seed inoculated with T. reesei+ Pathogen & $93 \pm 1.03 \mathrm{~b}$ & $9 \pm 0.43 \mathrm{c}$ \\
\hline
\end{tabular}

Means \pm standard deviation with in a column followed by the same letter are not significantly different at $\mathrm{P}=0.05$ when compared by Duncan test

Env. Biodiv. Soil Security Vol. 5 (2021) 
The improvement of chlorophyll contentmay helpin the development of the plant by making physiological operations work better through increasing the metabolic processes of carbon. On the other hand, the increment of chlorophyll content will be increasing the metabolismofcarbohydrates compounds by fixation of $\mathrm{CO}_{2}$ (Hopkins, 1999).

Inthis study, the increase inchlorophyll content of tomato leaves may besubject tonitrogena vailability for the plantby biocontrol agent strains. Hashem et al. (2017) reported that the inoculation with $B$. subtilis induced the chlorophyll pigments synthesis. The photosynthetic pigments such as chlorophyll-a and b were reduced in uninoculated one (control). However, the inoculation of $B$. subtilis stimulates an increase of total chlorophyll by a rate $33.61 \%$. Additionally, Al-Ezerjawi and Kadhim (2014) stated that T. harzianum might have colonizedaround theroot, increased therootbiomass and increased the availability of nutrients as well as interacted with the plant for exchangemetabolitesand that could cause significant changesin plant metabolism.

\section{Defense enzymes in tomato}

The data in Table 6 showed that there was a markable increase in the induction of defense enzymes (peroxidase, polyphenoloxidase, and chitinase) in the treated tomato as compared to the control. The inoculation of B. subtilis MK537378 and T. reesei MK934489 in presence of $P$. debaryanum induced high activities of peroxidase, polyphenoloxidase, and chitinase by increasing 49.3, 55.2 and 56.9\%, respectively, over the control. Microbial-induced resistance, a novel mechanism that explains the ability of biocontrol agents to suppress phytopathogens in plants, is recently known. These results are similar to those of Li et al. (2008) who reported that the inoculation with B. subtilis AR12 induced systemic resistance against tomato pathogen. The production of antioxidant enzymes in the plant was increased significantly after $B$. subtilis AR12 induced compared to the controls.

TABLE 4. Effect of inoculation tomato with B. subtilis MK537378 and T. reesei MK934489 on damping-off and disease incidence in soil infested with $P$. debaryanum

\begin{tabular}{lccc}
\hline \multirow{2}{*}{ Treatment } & \multicolumn{2}{c}{ Damping-off and survival plants } \\
\cline { 2 - 4 } & \% pre-emergence & \% post-emergence & \% survival plants \\
\hline Non-infested soil (control) & $6.67 \pm 0.58 \mathrm{~d}$ & $0.00 \pm 0.0 \mathrm{~b}$ & $93.3 \pm 0.6 \mathrm{a}$ \\
Soil infested with P. debaryanum & $50.00 \pm 2.5 \mathrm{a}$ & $38.33 \pm 2.6 \mathrm{a}$ & $11.7 \pm 1.9 \mathrm{c}$ \\
P. debaryanum + T. reesei & $16.67 \pm 1.44 \mathrm{~b}$ & $4.17 \pm 0.8 \mathrm{~b}$ & $79.2 \pm 0.8 \mathrm{~b}$ \\
P. debaryanum + B. subtilis & $20.00 \pm 1.53 \mathrm{~b}$ & $7.87 \pm 1.9 \mathrm{~b}$ & $72.1 \pm 2.5 \mathrm{~b}$ \\
P. debaryanum + T. reesei + B. subtilis & $13.33 \pm 0.58 \mathrm{c}$ & $3.70 \pm 0.7 \mathrm{~b}$ & $83.0 \pm 1.0 \mathrm{ab}$ \\
\hline
\end{tabular}

Means \pm standard deviation with in a column followed by the same letter are not significantly different at $\mathrm{P}=0.05$ when compared by Duncan test

TABLE 5. Effect of the inoculation of T. reesei MK934489 and B. subtilis MK537378 on dehydrogenase activity intomat or hizosphere of soil infested with $P$. debaryanum

\begin{tabular}{lcccc}
\hline \multirow{2}{*}{ Treatment } & \multicolumn{4}{c}{ Dehydrogenase activity } \\
\cline { 2 - 5 } & Initial & $\mathbf{3 0}$ & $\mathbf{6 0}$ & $\mathbf{9 0}$ days \\
\hline Non-infested soil (control) & $24.10 \pm 1.67 \mathrm{~d}$ & $32.55 \pm 2.25 \mathrm{~d}$ & $37.14 \pm 2.57 \mathrm{e}$ & $31.50 \pm 2.18 \mathrm{~d}$ \\
Soil infested with P. debaryanum & $29.62 \pm 2.05 \mathrm{~b}$ & $32.55 \pm 2.23 \mathrm{~d}$ & $33.48 \pm 2.31 \mathrm{~d}$ & $30.67 \pm 2.12 \mathrm{e}$ \\
P. debaryanum + T. reesei & $29.42 \pm 2.03 \mathrm{ab}$ & $34.01 \pm 2.35 \mathrm{c}$ & $43.08 \mathrm{v} \pm 2.98 \mathrm{c}$ & $39.12 \pm 2.70 \mathrm{c}$ \\
P. debaryanum + B. subtilis & $27.12 \pm 1.87 \mathrm{c}$ & $38.70 \pm 2.68 \mathrm{~b}$ & $46.21 \pm 3.19 \mathrm{~b}$ & $40.47 \pm 2.80 \mathrm{~b}$ \\
P. debaryanum + T. reesei + B. subtilis & $29.83 \pm 2.06 \mathrm{a}$ & $39.43 \pm 2.73 \mathrm{a}$ & $48.30 \pm 3.34 \mathrm{a}$ & $45.38 \pm 3.14 \mathrm{a}$ \\
\hline
\end{tabular}

Means \pm standard deviation with in a column followed by the same letter are not significantly different at $\mathrm{P}=0.05$ when compared by Duncan test 
Moreover, Chen et al. (2005) state that once the Trichoderma spp. colonized the roots, the plant defense responses can become systemic and protect the entire plant from a range of pathogens and diseases. T. harzianum strain T22 was not only able to promote seedling growth but also induced plant resistance. In the current study, the reduction in tomato root rot disease incidence due to B. subtilis MK537378 and T. reesei MK934489 application may be due to an increase in the defense-related enzymes such as peroxidase, polyphenoloxidase and chitinase beside the ability of those strains to produce cellulases that destroyed cell wall of the pathogen. The defense enzymes play an important role in induced resistance by incorporating toxic products into plant cell walls, which reduce fungal activity. For example, the oxidation of phenols to oxidized toxic products (quinine), incorporation of phenolic compounds, and lignification of plant cell walls (Małolepsza et al., 2017).

Peroxidase and polyphenoloxidase activity significantly increased in inoculated with $T$. reese $i$ MK934489 than that inoculated with B. subtilis MK537378. However, tomato inoculated with B. subtilis MK537378 observed higher values of chitinase activity compared with that inoculated with T. reesei MK934489.

\section{Effectsontomato growth parameters and yield}

The data presented in Table 8 revealed low values of the grow thparameters and yield of tomato plants, i.e., plant height, number of branches, plant dry weight, yield perplant and yield perfed danininfested soil with $P$. debaryanum solely compared with the other treatments. The grow thparameters and yield of the tomato plants increased significantly inresponse to the inoculation of B. subtilis MK537378 and T. reesei MK934489 compared to individual inoculation (Fig. 4). The present data are inaccordance with those obtainedby Shams et al. (2013) who state that the dual inoculation with plant growth-promoting bacteria gavea significant increase in all growth parameters and yield on lettuce compared with an individual one. Moreover, Zaghloul et al. (2007), reported that the use of biocontrolagents solelyorin combination led toa significant increase in the number of tomatofruitsper plant, the weight offruits and the totalfruit yield.

Plant grow th e nhancement by $B$. subtilis MK537378 and T. reesei MK934489

Env. Biodiv. Soil Security Vol. 5 (2021) isdone through different mechanisms such as secretion of plant grow thregulators (Hoitink et al. 2006; Vinale et al. 2008 and Hashem et al. 2017), phosphates, and micronutrient solubilization (Altomare et al. 1999), secretion of exogenousenzymes, siderophores (Jalal et al. 1987) and vitamins (Inbar et al. 1994), as well as indirectly with the control of themajor and minorrootinfestingpathogensinthe rhizosphere (Harman et al. 2004).

Depending on the data in Tables 5 and 7 , it could be noticed that the effective role of inoculation with biocontrol agent on the enhancement of microbial community and plant chlorophyll as well as second arymetabolites such as auxin-like compounds that might be as on for the improved growth and increased yield. Besides, root colonization increases the growth of the entire plant and thus increases plant productivity and yields. Symbiotic association with microbes' rhizosphere and the plant helps to surmount biotic stress and improve nutrient uptake (Harman et al. 2004). Also, Hashem et al. (2017) reported that B. subtilis enhanced the uptake of some macro- and micronutrient which led to enhance the plant growth at disease conditions and might be due to the regulation of various metabolic pathways such as antioxidant system and chlorophyll synthesis.

\section{Conclusion}

From the obtained results it can be concluded that B. subtilis MK537378 and T. reesei MK934489 showed high potent to produce cellulase enzymes and antagonistic activity against $P$. debaryanum. Microscopic have been conducted to show the role of cellulose-degrading enzymes in controlling the fungus or not, and the results have shown the mycelia of $P$. debaryanum were completely lysed at a lot of regions even the cytoplasm went out through the lysed regions. Greenhouse study was conducted on tomato and the results confirmed that damping-off disease caused by Pythium debaryanum can be controlled by using the culture of cellulases enzymes producers Bacillus subtilis MK537378 and Trichoderma reesei MK934489. Moreover, markable increase in the induction of defense enzymes (peroxidase, polyphenoloxidase, and chitinase), growth parameters, and yield of tomato plants were observed. Considering these facts as well as other features of B. subtilis MK537378 and T. reesei MK934489 strains, further investigations are ongoing in our laboratories. 


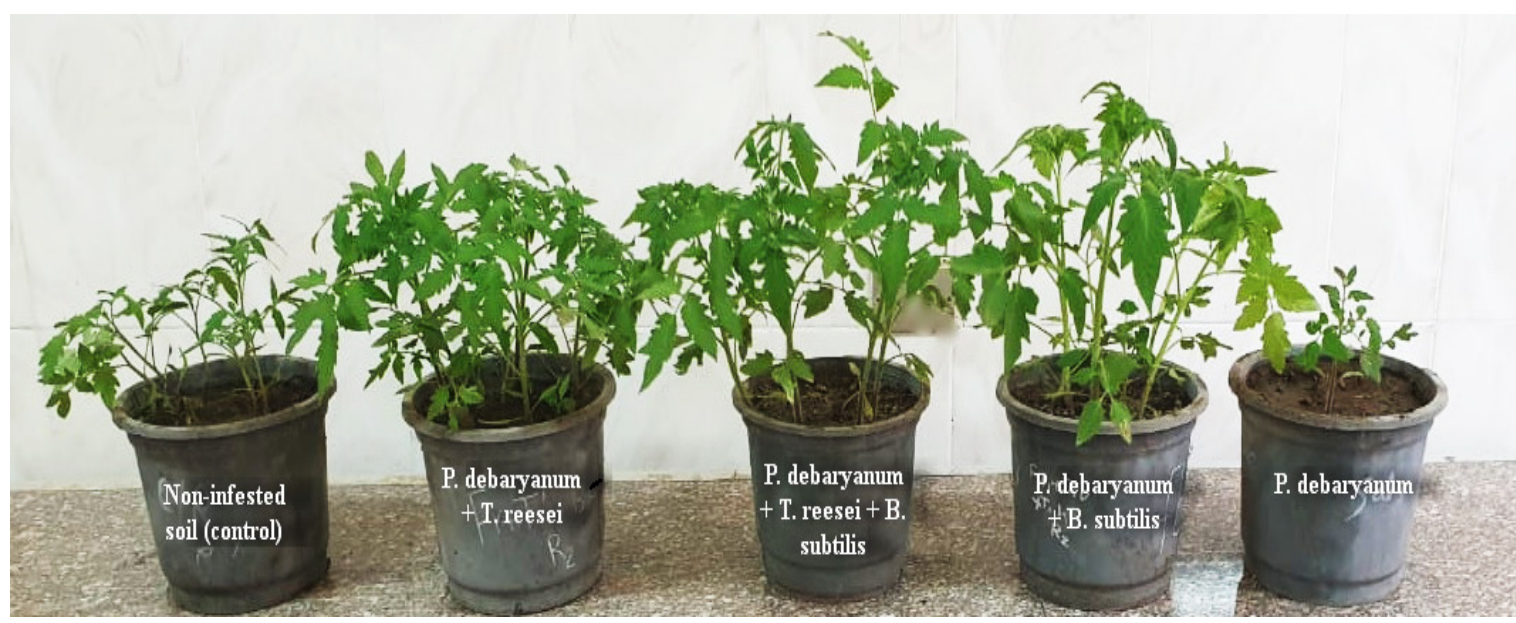

Fig. 4. Effect of inoculation with B. subtilis MK537378 and T. reesei MK934489 on tomato vegetative growth at 45DAS compared with infested and non-infested treatments

TABLE 6. Peroxidase, polyphenoloxidase and chitinase activities in tomato leave affected by the inoculation with T.reesei MK 934489 and B.subtilis MK537378 in presence of $P$. debaryanum

\begin{tabular}{lccc}
\hline \multirow{2}{*}{ Treatment } & \multicolumn{3}{c}{ Enzymeactivities } \\
\cline { 2 - 4 } & Peroxidase & Polyphenoloxidase & Chitinase \\
\hline Non-infested soil (control) & $0.224 \pm 0.02 \mathrm{e}$ & $0.304 \pm 0.02 \mathrm{e}$ & $0.736 \pm 0.05 \mathrm{e}$ \\
Soil infested with P. debaryanum & $0.335 \pm 0.02 \mathrm{~d}$ & $0.490 \pm 0.03 \mathrm{~d}$ & $0.959 \pm 0.07 \mathrm{~d}$ \\
P. debaryanum + T. reesei & $0.406 \pm 0.03 \mathrm{~b}$ & $0.622 \pm 0.04 \mathrm{~b}$ & $1.317 \pm 0.09 \mathrm{c}$ \\
P. debaryanum + B. subtilis & $0.349 \pm 0.02 \mathrm{c}$ & $0.570 \pm 0.04 \mathrm{c}$ & $1.403 \pm 0.10 \mathrm{~b}$ \\
P. debaryanum + T. reesei + B. subtilis & $0.442 \pm 0.03 \mathrm{a}$ & $0.678 \pm 0.01 \mathrm{a}$ & $1.709 \pm 0.02 \mathrm{a}$ \\
\hline
\end{tabular}

Means \pm standard deviation with in a column followed by the same letter are not significantly different at $\mathrm{P}=0.05$ when compared by Duncan test

TABLE 7. Effect of application of T. reesei MK934489 and B. subtilis MK537378 on chlorophyll content in tomato cultivated in soil infested with $P$. debaryanum

\begin{tabular}{lccc}
\hline \multirow{2}{*}{ Treatment } & \multicolumn{2}{c}{ Chlorophyll content (mg.g - $^{-1}$ fresh leaves) } \\
\cline { 2 - 3 } & Chlorophyll a & Chlorophyll b & Chlorophyll (a+b) \\
\hline Non-infested soil (control) & $2.30 \pm 0.12 \mathrm{~b}$ & $1.04 \pm 0.05 \mathrm{~b}$ & $3.34 \pm 0.18 \mathrm{~b}$ \\
Soil infested with P. debaryanum & $1.45 \pm 0.44 \mathrm{c}$ & $0.72 \pm 0.22 \mathrm{~b}$ & $2.17 \pm 0.65 \mathrm{c}$ \\
$P$. debaryanum + T. reesei & $3.32 \pm 0.72 \mathrm{a}$ & $1.65 \pm 0.36 \mathrm{a}$ & $4.97 \pm 1.08 \mathrm{a}$ \\
P. debaryanum + B. subtilis & $3.44 \pm 0.71 \mathrm{a}$ & $1.72 \pm 0.36 \mathrm{a}$ & $5.16 \pm 1.07 \mathrm{a}$ \\
P. debaryanum + T. reesei + B. subtilis & $3.87 \pm 0.56 \mathrm{a}$ & $1.92 \pm 0.28 \mathrm{a}$ & $5.79 \pm 0.84 \mathrm{a}$ \\
\hline
\end{tabular}

\footnotetext{
${ }^{\text {(a) }}$ Means \pm standard deviation with in a column followed by the same letter are not significantly different at $\mathrm{P}=0.05$ when compared by Duncan test.
} 
TABLE 8. Effect of application of T.reesei MK934489 and B.subtilis MK537378 on tomato growth parameters and yield.

\begin{tabular}{lccccc}
\hline Treatment & $\begin{array}{c}\text { Plant height } \\
\text { (cm) }\end{array}$ & $\begin{array}{c}\text { No. of } \\
\text { branches }\end{array}$ & $\begin{array}{c}\text { Plant dry } \\
\text { weight }(\mathbf{g})\end{array}$ & $\begin{array}{c}\text { Yield/plant } \\
\text { (kg) }\end{array}$ & $\begin{array}{c}\text { Yield/fed. } \\
\text { (metric ton) }\end{array}$ \\
\hline Non-infested soil (control) & $42.4 \pm 2.87 \mathrm{c}$ & $3.8 \pm 0.45 \mathrm{~b}$ & $8.78 \pm 0.55 \mathrm{c}$ & $0.80 \pm 0.07 \mathrm{c}$ & $18.3 \pm 1.64 \mathrm{c}$ \\
Soil infested with P. debaryanum & $33.0 \pm 3.29 \mathrm{~d}$ & $2.2 \pm 0.55 \mathrm{c}$ & $5.62 \pm 0.61 \mathrm{~d}$ & $0.38 \pm 0.13 \mathrm{~d}$ & $8.7 \pm 3.00 \mathrm{~d}$ \\
P. debaryanum + T. reesei & $53.6 \pm 3.90 \mathrm{~b}$ & $5.6 \pm 0.45 \mathrm{a}$ & $12.12 \pm 0.82 \mathrm{~b}$ & $1.32 \pm 0.09 \mathrm{~b}$ & $30.4 \pm 2.06 \mathrm{~b}$ \\
P. debaryanum + B. subtilis & $54.1 \pm 4.17 \mathrm{~b}$ & $5.8 \pm 0.45 \mathrm{a}$ & $14.64 \pm 0.76 \mathrm{a}$ & $1.38 \pm 0.08 \mathrm{ab}$ & $31.7 \pm 1.92 \mathrm{ab}$ \\
P. debaryanum + T. reesei + B. subtilis & $64.2 \pm 4.81 \mathrm{a}$ & $6.2 \pm 0.45 \mathrm{a}$ & $15.38 \pm 1.03 \mathrm{a}$ & $1.44 \pm 0.08 \mathrm{a}$ & $33.1 \pm 1.92 \mathrm{a}$ \\
\hline
\end{tabular}

\section{Ethics approval and consent to participate}

This article does not contain any studies with human participants or animals performed by any of the authors.

\section{Consent for publication}

All authors declare their consent for publication.

\section{Contribution of authors}

This study was designed and implemented by all the authors, where all contributed to writing the manuscript, interpreting information presented and have read and agreed to the final version of the manuscript.

\section{Funding}

This research received no external funding.

\section{Conflicts of Interest}

The author declares no conflict of interest.

\section{Acknowledgment}

The authors would like to express sincere appreciation to all staffmembers of Agric. Microbiology Dept., Faculty of Agriculture at Moshtohor, Benha University, for their kind cooperation.

\section{References}

Abd-Elgawad MM (2020) Optimizing biological control agents for controlling nematodes of tomato in Egypt. Egyptian Journal of Biological Pest Control, 30, 1-10.

Abdel-Rahman HM, Salem AA, Moustafa MM, ElGarhy, HA (2017) A novice Achromobacter sp. EMCC1936 strain acts as a plant growth-promoting agent. Acta Physiologiae Plantarum, 39 (2), 61.

Abdelrahman HM (2009) Bio-organic farming efficiency on yield and quality of some medicinal plants (Doctoral dissertation, Ph. D. Thesis, Botany Department, Faculty of Agriculture, Moshtohor, Benha University).

Abdullah TM, Ali YN, Suleman P (2008) Biological control of Sclerotinia sclerotiorum (Lib.) de Bary with Trichoderma harzianum and Bacillus amyloliquefaciens. Crop Prot. 27: 1354-1359.

Al-Ezerjawi NH, Kadhim JH (2014) Effect of Two Isolates of Trichodermaharzianum on Total Nitrogen, Chlorophyll a \& b Contents and Yield of Wheat (Triticum aestivum. L) Class Eba'a-95.

Altomare C, Norvell WA, Björkman T, Harman GE (1999) Solubilization of phosphates and micronutrients by the plant-growth-promoting and biocontrol fungus Trichodermaharzianum Rifai 1295-22. Appl Environ Microbiol. 65:2926-2933.

Ashwini N, Srividya S (2014) Potentiality of Bacillus subtilis as biocontrol agent for management of anthracnose disease of chilli caused by Colletotrichum gloeosporioides OGC1. 3 Biotech, 4 (2), 127-136.

Bae H, Sicher RC, Kim MS, Kim SH, Strem MD, Melnick RL, Bailey B (2009) The beneficial endophyte Trichoderma hamatum isolate DIS $219 \mathrm{~b}$ promotes growth and delays the onset of the drought response in Theobroma cacao. Journal of Experimental Botany, 60 (11), 3279-3295.

Bákonyi N, Bott S, Gajdos E, Szabó A, Jakab A, Tóth B, Makleit P, Veres S (2013) Using Biofertilizer to Improve Seed Germination and Early Development of Maize. Polish Journal of Environmental Studies, 22 (6), 1595-1599.

Bashan Y, Okon Y, Henis Y (1985) Peroxidase, polyphenol oxidase, and phenols in relation to resistance against 214 Pseudomonas syringaepv. tomato in tomato plants. Can J Bot. 65, 366-372. 
Benhamou N, Rey K, Picard Y (1999) Ultraestructural and cyto chemical aspects of the interaction between the mycoparasite Pythium oligandrum and soil borne plant pathogens. Phytopathology 89, 506-517.

Berghem LER and Petterson LG (1974) The mechanism of enzymatic cellulose degradation: Isolation and some properties of $\beta$-glucosidase from Trichoderma koningii. Eur. J Biochem. 46, 295-305.

Björkman T, Blanchard LM, Harman GE (1998) Growth enhancement of shrunken-2 (sh2) sweet corn by Trichoderma harzianum 1295-22: effect of environmental stress. Journal of the American Society for Horticultural Science, 123 (1), 35-40.

Bruce A, Srinivasan U, Staines HJ, Highley TL (1995) Chitinase and laminarinase production in liquid culture by Trichoderma spp. and their role in biocontrol of wood decay fungi. International Biodeterioration \& Biodegradation, 35 (4), 337353.

Chen R, Harman GE, AfiocoMI, Cheng SG (2005) Proteins related to the biocontrol of Pythium damping-off in maize with Trichoderma harzianum. J Integr Plant Biol. 47 (8):988-997.

Elad Y (2000) Biological control of foliar pathogens by means of Trichoderma harzianum and potential modes of action. Crop Prot 19:709-714.

El-feky N, Essa T, Elzaawely AA, El-Zahaby HM (2019) Antagonistic activity of some bioagents against root rot diseases of pepper (Capsicum annum L.). Environment, Biodiversity and Soil Security, 3 (2019), 215-225.

Elshahawy I, Abouelnasr HM, Lashin SM, Darwesh OM(2018) First report of Pythium aphanidermatum infecting tomato in Egypt and its control using biogenic silver nanoparticles. Journal of Plant Protection Research, 58 (2).

Fadeel AA (1962) Location and properties of chloroplasts and pigment determination in roots. Physiologia plantarum, 15 (1), 130-146.

Ghazi AA, Attia EA, Rashed NM (2018) Management of charcoal rot (Macrophominaphaseolina) infection in geranium (Pelargonium graveolens L.) using biocontrol agents and essential oils. Environment, Biodiversity and Soil Security, 2 (2018), 131-142.

Hariprasad P, Niranjana SR (2009) Isolation and characterization of phosphate solubilizing rhizobacteria to improve plant health of tomato. Plant and Soil, 316 (1), 13-24.

Harman GE (2006) Overview of mechanisms and uses of Trichoderma spp. Phytopathology 96, 190-194.

Harman GE, Bjorkman T. (1998) Potential and existing uses of Trichoderma and Gliocladium for plant disease control and plant growth enhancement. Trichoderma and Gliocladium: Enzymes, biological control and commercial applications. Vol. 2. London: Taylor \& Francis Ltd,. pp. 229-65.

Hashem A, Abd-Allah EF, Alqarawi AA, Radhakrishnan R, Kumar A (2017) Plant defense approach of Bacillus subtilis (BERA71) against Macrophominaphaseolina (Tassi) Goid in mung bean. Journal of Plant Interactions, 12 (1), 390401.

Hendricks CW, Doyle JD, Hugley B (1995) A new solid medium for enumerating cellulose-utilizing bacteria in soil. Applied and Environmental Microbiology, 61(5), 2016-2019.

Hoitink HAJ, Madden LV, Dorrance AE (2006) Systemic resistance induced by Trichoderma spp. interactions between the host, the pathogen, the biocontrol agent, and soil organic matter quality. Phytopathology 96,186-189.

Hopkins WG (1999) Introduction to plant physology. 2nd edn. John Wiley and Sons, Inc. USA

Ihrmark K, Asmail N, Ubhayasekera W, Melin P, Stenlid J, Karlsson M (2010) Comparative molecular evolution of Trichoderma chitinases in response to mycoparasitic interactions. Evol Bioinform 6,1-26

Inbar J, Abramsky M, Cohen D, Chet I (1994) Plant growth enhancement and disease control by Trichoderma harzianum in vegetable seedlings growth under commercial conditions. Eur J Plant Pathol. 100, 337-346

Jalal MAF, Love SK, Van der Helm D (1987) Siderophore mediated iron (III) uptake in Gliocladium virens (Trichoderma virens). 2. Role of ferric mono and dihydroxamates as iron transport agents. J. InorganBiochem. 29:259-267.

Joseph B, Ranjan Patra R, Lawrence R. (2007) Characterization of plant growth promoting rhizobacteria associated with chickpea (Cicer arietinum L.). International Journal of Plant Production, 1 (2), 141-152.

Kamil Z, Rizk M, Saleh M, Moustafa S (2007) Isolation Env. Biodiv. Soil Security Vol. 5 (2021) 
and identification of rhizosphere soil chitinolytic bacteria and their potential in antifungal biocontrol. Global J Mol Sci. 2, 57-66

Khare A, Upadhyay RS, (2009) Induction of mutant strains of Trichoderma viride 1433 for biocontrol of Pythium aphanidermatum. Environ. Biol. Conserv. 14, 123-567.

Kipngeno P, Losenge T, Maina N, Kahangi E, Juma P (2015) Efficacy of Bacillus subtilis MK537378 and Trichoderma asperellum against Pythium aphanidermatum in tomatoes. Biological Control, 90, 92-95.

Kloepper, J. W., Ryu, C. M., \& Zhang, S. (2004). Induced systemic resistance and promotion of plant growth by Bacillus spp. Phytopathology, 94 (11), 1259-1266.

Kumar S, Roy PD, Lal M, Chand G, Singh V (2014) Mass multiplication and shelf life of Trichoderma species using various agro products. Int Quar J Life Sci. 9:1143-1145

Lee TT (1973) On extraction and quantitation of plant peroxidase isoenzymes. Physiol Plant 29:198-203

Li SM, Hua GG, Liu HX, Guo JH (2008) Analysis of defence enzymes induced by antagonistic bacterium Bacillus subtilis MK537378 strain AR12 towards Ralstonia solanacearum in tomato. Annals of Microbiology, 58 (4), 573-578.

Małolepsza U, Nawrocka J, Szczech M (2017) Trichoderma virens 106 inoculation stimulates defence enzyme activities and enhances phenolic levels in tomato plants leading to lowered Rhizoctonia solani infection. Biocontrol Sci Tech. 27 (2):180-199.

Monreal J, Reese ET (1969) The chitinase of Serratia marcescens. Can J Microbiol. 15, 689-696.

Moran R, Porath D (1980) Chlorophyll determination in intact tissues using $\mathrm{N}, \mathrm{N}$-dimethylformamide. Plant Physiology, 65 (3), 478-479.

Montero M, Sanz L, Rey M, Llobell A, Monte E (2007) Cloning and characterization of bgn16_3, coding for a $\beta$-1, 6-glucanase expressed during Trichoderma harzianum mycoparasitism. J Appl Microbiol. 103:1291-1300

Muriungi SJ, Mutitu EW, Muthomi JW (2014) Efficacy of cultural methods in the control of Rhizoctonia solani strains causing tomato damping-off in Kenya. African Journal of Food, Agriculture, Nutrition and Development, 14 (2).
Podile AR, Prakash AP (1996) Lysis and biological control of Aspergillus niger by Bacillus subtilis MK537378 AF 1. Canadian Journal of Microbiology, 42 (6), 533-538.

Rini CR, Sulochana KK (2007) Management of seedling rot of chili (Capsicum annuum L.) using Trichoderma spp. and fluorescent pseudomonads (Pseudomonas fluorescens). Journal of Tropical Agriculture, 44, 79-82.

Rosenzweig C, EIglesias A, Yang XB, Epstein PR, Chivian E (2001) Climatechange and extreme weather events: implications for food production, plantdiseases, and pests. Global Change Hum. Health 2, 90-104.

Saadia M, Ahmed S, Jamil A (2008) Isolation and cloning of cre1 gene from a filamentous fungus Trichoderma harzianum. Pakistan Journal of Botany, 40 (1), 421-426.

Salem AA, Abdel-Rahman HM (2015) Optimization and characterization of cellulolytic enzymes produced from Gliocladiumroseum. Journal of Agricultural Chemistry and Biotechnology, 6 (11), 473-488.

Schinner F, Oehlinger R, Kandeler E, Margesin R (1996) Methods in soil biology. Springer Lab Manuals. Part I:213-241.

Shams AS, Abdel-Rahman HM, El-Ramady HR (2013) Evaluation of integrated nutrient management practices for lettuce production under drip irrigation system. Journal of Applied Sciences Research, 9 (3), 2223-2231.

Sharma I. (2021) Phytopathogenic fungi and their biocontrol applications. In Fungi Bio-Prospects in Sustainable Agriculture, Environment and NanoTechnology (pp. 155-188). Academic Press.

Singh R, Upadhyay SK, Singh M, Sharma I, Sharma P, Kamboj P, Khan F (2021) Chitin, chitinases and chitin derivatives in biopharmaceutical, agricultural and environmental perspective. Biointerface Res Appl Chem, 11(3), 9985-10005.

Sivan A, Elad Y, Chet I (1984) Biological control effects of new isolate of Trichoderma harzianum on Phythiumaphanidermatum. Phytopathology 74:498-501.

Taha N, Kamel S, Elsakhawy T, Bayoumi Y, Omara AED, El-Ramady HR (2020) Sustainable Approaches of Trichoderma under Changing Environments for Vegetable Production. 
Environment, Biodiversity and Soil Security, 4

(2020), 291-311.

Turner JT, Backman PA (1991) Factors relating to peanut yield increases following Bacillussubtilis seed treatment. Plant Dis, 75, 347-353.

Vinale F, Sivasithamparam K, Ghisalberti EL, Marra R, Woo SL, Lorito M (2008) Trichodermaplant-pathogen interactions. Soil Biology and Biochemistry, 40 (1), 1-10.

Wettestein D (1957) Chlorophyll-lethal under submicroscopic change in shape of the plastids. Expt Cell Res. 12, 427-500.

Woo S, Lorito M (2007) Exploiting the interactions between fungal antagonists, pathogens and the plant for biocontro. In: Vurro M, Gressel J (Eds) Novel biotechnologies for biocontrol agent enhancement and management. Springer, Netherlands, pp 107-130.

Wood TM and Bhat KM (1998) Method for measuring cellulase activities. In Methods in Enzymology. Cellulose and Hemicellulose, Eds W.A. Wood and J.A. Kellogg, Vol. 160, pp. 87-112. Academic Press, New York

Zaghloul RA, Hanafy EA, Neweigy NA, \& Khalifa NA (2007, March) Application of biofertilization and biological control for tomato production. In $12^{\text {th }}$ Conference of Microbiology (pp. 18-22).

Zitnick-Anderson KK, Norland JE, Luis E, Fortuna AM, Nelson BD (2017) Probability models based on soil properties for predicting presence-absence of Pythium in soybean roots. Microbial Ecology, 74 (3), 550-560. 